\title{
Border Disputes between China and North Korea
}

Daniel Gomà Pinilla

\section{OpenEdition}

\section{Journals}

\section{Electronic version}

URL: http://journals.openedition.org/chinaperspectives/806

DOI: 10.4000/chinaperspectives.806

ISSN: 1996-4617

\section{Publisher}

Centre d'étude français sur la Chine contemporaine

\section{Printed version}

Date of publication: 1 March 2004

ISSN: 2070-3449

\section{Electronic reference}

Daniel Gomà Pinilla, "Border Disputes between China and North Korea », China Perspectives [Online], 52 I march-april 2004, Online since 23 April 2007, connection on 28 October 2019. URL : http:// journals.openedition.org/chinaperspectives/806 ; DOI : 10.4000/chinaperspectives.806

This text was automatically generated on 28 October 2019

(c) All rights reserved 


\title{
Border Disputes between China and North Korea
}

\author{
Daniel Gomà Pinilla
}

\section{EDITOR'S NOTE}

Translated from the French original by Peter Brown

1 The Democratic People's Republic of Korea (DPRK) and the People's Republic of China (PRC) have enjoyed relatively stable relations since they came into being in 1948 and 1949 respectively. The Korean War (1950-53) set the scene for future relations between Pyongyang and Peking, given that Chinese help was vital for the survival of Kim IlSung's regime. Sino-North Korean relations experienced periods of great strain during the 1960s and 1970s, when the Sino-Soviet conflict divided the Communist bloc into pro-Soviet and pro-Chinese camps. However, Peking was able to take advantage of the internal and external problems of the DPRK to present itself as Pyongyang's main friend faced with the pressures exerted by South Korea and the West-the USA inter alia-which occurred all the more easily after the collapse of the USSR.

2 Although, at the time both regimes were being established, Peking and Pyongyang declared that a new era was dawning, neither country has been able to completely free itself of the shackles of its historical heritage. Past Chinese domination on the Korean peninsula still causes resentment today in North Korea. Since the death of Kim Il-Sung (1994), China has seen a decline in its influence, although the issue of North Korea's nuclear programme allows it today to again play an important role in Northeast Asia. The authorities in Peking are aware that in addition to the problems created by the nuclear ambitions of Kim Jong-Il's regime and the growing presence of North-Korean refugees on Chinese soil, there is the issue of territorial disputes between the two countries.

China and North Korea share a 1,416-kilometre long border that corresponds broadly speaking to the course of the Yalu and Tumen rivers. These rivers have facilitated the 
drawing up of the borders, but the agreements between the two countries have not been without considerable tensions, mainly due to Pyongyang. North Korea resolved its border disputes with Russia (the then USSR) in 1985-86, but its territorial problems with China have still to be settled. A lack of proper documentation hampers study of this question, and Pyongyang has never made its territorial claims a determining factor of its foreign policy. Most of our information comes from statements made, under cover of anonymity, by North Korean diplomats posted to Third World countries. Peking for its part never comments officially on the subject. Moreover, access to the border zone has for a long time been restricted, thus preventing any in situ research. Finally, the territorial dispute has never constituted the threat of a break in relations between the two countries.

4 However, in spite of the image of "indestructible" friendship between the two countries, the border disputes have in fact conditioned their relations since 1950. For China, the polemic with North Korea is just one in a long line of territorial disputes with neighbouring countries, concerning both land and maritime boundaries. Secret negotiations between Peking and Pyongyang resulted in 1963 in an agreement that seems to be no longer valid today. At the time, at the height of the Sino-Soviet standoff, China adopted a flexible position in order to break out of its isolation in the Communist bloc and to win Kim Il-Sung's regime ${ }^{1}$ over to its cause. In spite of the CCP's tough stance after 1949 in the face of the territorial claims made by its neighbouring countries, Premier Zhou Enlai advised the Chinese delegation to be receptive to North Korea's demands. The Chinese concessions were so significant that the local authorities in the border provinces of Jilin and Liaoning protested ${ }^{2}$.

The Sino-Korean border has been changed a great deal over the centuries. The Korean kingdom of Koguryo (fifth to eighth centuries) controlled Manchuria and the region around present-day Vladivostok. The kingdom of Parhae (eighth to tenth centuries) that succeeded it dominated Manchuria and the Liaodong peninsula, although in the seventh century the power of the Chinese Tang Empire had reached as far as Seoul. The present borders correspond roughly to those of the Yuan Empire (1279-1368). The Manchu Qing dynasty (1644-1911) consolidated the Chinese domination of the Northeastern region. At the time, Korea was a satellite state of China, subject to the authority of the "Son of Heaven", and the kings in Seoul were in no position to oppose Chinese demands. Yet, in the nineteenth century, a period of decline for the Chinese empire, Korea made its displeasure known and Seoul called, albeit unsuccessfully, for the restitution of territories formerly under Korean domination. However, China's defeat at the hands of Japan in 1895 and Tokyo's gradual domination on the Korean peninsula put an end to any possibility of agreement.

6 North Korea often maintains that the territorial squabble has its origins in the relations of dependency between Korea and China in the period of the Manchu Qing dynasty, even though the Han, the main ethnic group of the "Middle Kingdom", were not in power. China, however, considers that the territories acquired in the past are no longer subject to further discussion today, especially if this should threaten the territorial integrity of the People's Republic. 


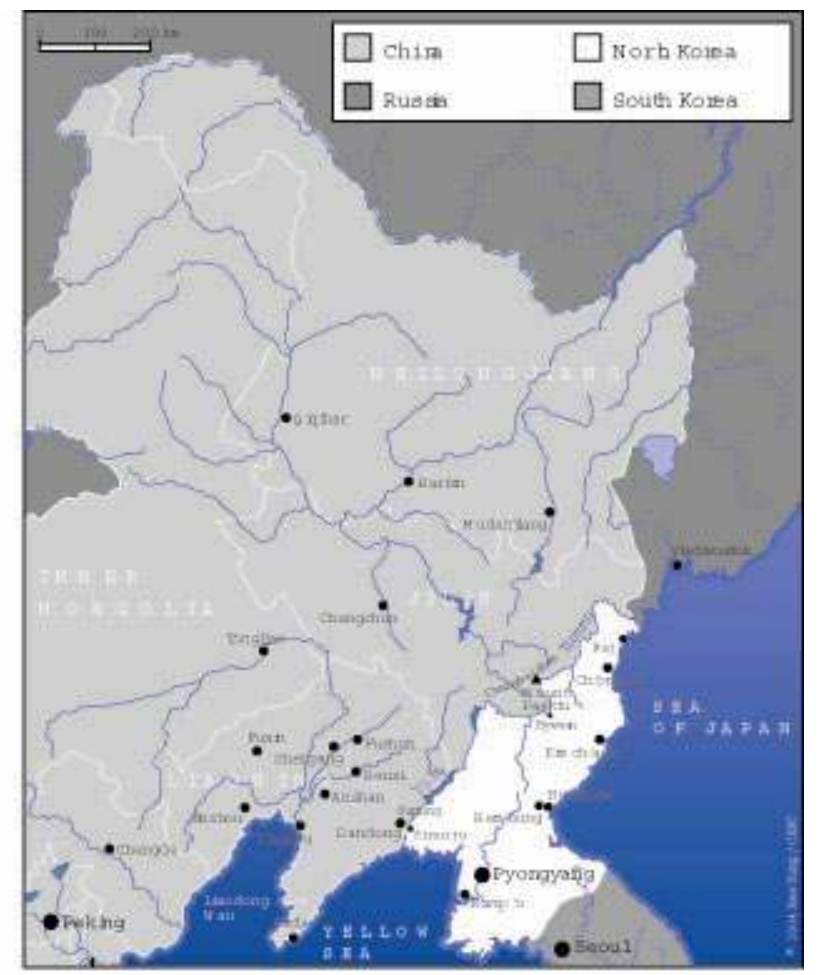

Paektusan, the "Sacred Mountain"

The principal border dispute between Peking and Pyongyang concerns Mount Paektu ${ }^{3}$. This is the region's highest peak, a 2,744-metre high volcano lying at the source of the Yalu and Tumen rivers. At the bottom of the crater lies a lake, 13 kilometres square and 204 metres deep, the Chongji ${ }^{4}$. Mount Paektu is part of the Changbaishan mountain range ("eternally white mountains" in Chinese), that crosses in a north-south direction the prefectures of Antu, Wusong and Changbai, in the south of Jilin province, stretching over 80 kilometres and ending inside Korea's borders ${ }^{5}$.

The Qing emperor Kangxi (1662-1723) forced Korea, which at the time was a vassal state of China, to accept that the border separating the two countries should pass through the Paektusan peak. The region in which the volcano is situated is regarded as the cradle of the Manchu people. The squabble over Mount Paektu resurfaced under King Kojong (1864-1907), from the Korean Yi dynasty, but the Japanese occupation of the Korean peninsula put an end to any possibility of compromise.

The zone surrounding the volcano is inhospitable and uninhabited, and neither the Koreans nor the Chinese have tried to develop the region economically. The territory claimed by Pyongyang concerns 33 square kilometres around the Paektusan summit. In the case of Lake Chongji, the 1963 agreement established that three-fifths would be under North Korea's control with the remaining two-fifths belonging to China.

In 1965, the standoff between China and the Soviet Union put North Korea in a very tight situation. Pyongyang needed the help of both countries: owing its existence to the former and its survival to the latter. Kim Il-Sung's criticism of any deviation in the international communist movement was very badly received by Peking and tensions mounted between Kim and Mao. In order to punish the North Korean regime for its lack of support, China is thought to have demanded that the 160 square kilometres around Paektusan be conceded to it as compensation for the economic and military aid 
provided by Peking during the Korean War $(1950-53)^{6}$. China abandoned its claim in November 1970 in order to improve relations with Pyongyang ${ }^{7}$. Between March 1968 and March 1969, various military skirmishes took place in the Paektusan region between the North Korean and Chinese armed forces. These were consequences of the tensions caused by the Cultural Revolution and the savage criticisms made of Kim IlSung by the Red Guards. During these years of unrest, Peking closed its border with its neighbour.

11 For the Koreans, Mount Paektu is entwined with their earliest history. According to legend, the God Hwanung ("the king come from the sky") landed on the volcano to couple with a woman who then conceived a son, Tangun ("the king of the birch-tree"), who in 2333 B.C. founded the kingdom of Choson, regarded as being the first Korean state.

Furthermore, for the communist authorities of North Korea, Mount Paektu is the "sacred mountain of the revolution", the place of the most important guerrilla exploits in the 1930s under the command of Kim Il-Sung. After Mangyongdae, the village in which Kim was born, the volcano is without doubt the most venerated place in the DPRK. One of the best-known photographs of the former leader shows him at the summit of Paektusan contemplating Lake Chongji. This is proof of the North Korean desire to affirm its pre-eminence over this territory. An image of Mount Paektu also decorates the main façade of the Korean Museum of the Revolution in Pyongyang, an enormous building that was constructed to the glory of the Great Leader's revolutionary past.

The volcano's importance for the regime is such that North Korean propaganda affirms that Kim Jong-Il was born in a guerrilla camp on the Korean face of Mount Paektusan in February 1942. In actual fact, the present North Korean leader was born in the military camp of Vyatsk, near the city of Khabarovsk in the Russian Far-East, where his father was an officer in the Red Army. The goal of this manipulation is clear: to situate the birth of the communist dictator on Korean soil and in a symbolic place that is representative of the consciousness of the Korean people ${ }^{8}$. The DPRK's leaders even invented the exact spot of his birth that has since become a place of worship and pilgrimage ${ }^{9}$.

14 To justify its control over a part of Paektusan, Peking talks about compensation for its military support of North Korea during the 1950-53 conflict. For some time now Peking has been constantly referring to its concern for the protection of the region's natural environment and for the development of the volcano as a tourist attraction ${ }^{10}$. China has a final argument to justify its control over Paektusan, which is that while the volcano may be sacred for Koreans, it is also sacred for Manchus ${ }^{11}$. Hiding behind the defence of the interests of Manchus, Peking rules out any negotiations that could lead to territorial loss in the area.

The Yalu and Tumen Rivers, and control of the seas

15 Since 1949, China and North Korea have accepted that the course of the Yalu and Tumen rivers constitute the border between the two countries. However, they have refused to situate the demarcation line in the middle of the rivers, adopting the principle of joint ownership, management and use of the two waterways.

16 Historically, the main problem has been over the dozens of islands that are to be found in the rivers. China has recognised North Korea's sovereignty over $80 \%$ of these islands, including the biggest ones. Ownership of the islands has been determined by the 
nationality of their population, but the problem has not been resolved at all for the uninhabited islands, a sort of shared responsibility seeming to apply in their case. Pidan (Chouduandao in Chinese), located at the mouth of the Yalu, was, however, an exception. The island was originally inhabited by mainly Chinese, and while North Korea had control over it, Peking officially regarded it as an integral part of its own territory. The North Koreans then wished to make a gift of it to China in gratitude for its help in 1950-53. In the event, this did not happen, and, in 1963, the Chinese authorities had to evacuate the approximately fifty families who were still living there ${ }^{12}$.

17 The river banks are also the subject of discussions, although both parties recognise that they serve as a line of demarcation between the two Communist states. Peking is showing tolerance towards the North Korean claims, yet without giving in to Pyongyang. The Chinese acceptance of North Korean control of $90 \%$ of the mouth of the Yalu was badly received by the local authorities in the Chinese border provinces, despite the state of free navigation stipulated by Peking. Management of the river ports has also been a factor of dispute. Finally, in October 2000, both countries reached an agreement on the border ports and their joint management ${ }^{13}$. In point of fact, friction over the control of the banks of the Yalu and Tumen explain the great number of agreements and protocols signed by Peking and Pyongyang: for example, the agreement on the management of the railway line running along the Yalu, on navigation and the electricity produced by both rivers, the floating of timber downstream, the common management of the Unbong hydroelectric plant, etc.

18 Another polemic of significance concerns the island of Shindo (Shin in Chinese), situated in the estuary of the Yalu River. In spite of Chinese claims, Shindo has for a long time belonged to Korea, and under Japanese occupation was a production centre for raw materials for textiles, as the place is covered in reeds. The Chinese authorities regard the island as a station of major importance for transport and communication in the development of oil extraction in the Gulf of Beihai. For Pyongyang, ownership of the island favours its strategic position at the mouth of a river that serves as a boundary-mark between the two countries ${ }^{14}$.

19 Another element of tension is the question of access to the Sea of Japan. Although the DPRK borders China along the greater part of its northern boundary, the last portion of the River Tumen (17 kilometres exactly) marks the limit between North Korea and Russia, thus depriving the Chinese of any opening onto the Sea of Japan. For China, not having any supply post for its war fleet in this zone puts a major break on its political and military presence in North Asia.

The 1985-86 and 1991 agreements between Russians and North Koreans on demarcating their borders are of vital interest for China, which is very concerned by the recognition of its navigation rights on the Tumen River as far as the Sea of Japan. The accords signed by Tsarist Russia and Imperial China in 1858 (Aigun Treaty) and 1860 (Peking Treaty) recognise Russia's possession of eastern Siberia and the extension of its territory as far as the Amour and Tumen rivers, but they also establish China's right to cross the Tumen in order to have access to the Sea of Japan. Moscow and Pyongyang have never denied China this right, but they have rarely shown any co-operative attitude either. For Pyongyang, Chinese access to the Sea of Japan threatens its independence. The improvement in relations between the Chinese and Russian authorities during the 1990s enabled a rapprochement and the signing of several 
agreements. The most recent one, a protocol signed in Peking on June 20th 2003, concerns the junction of the Chinese, Russian and North Korean borders on the river Tumen ${ }^{15}$. The main problem for China in this whole question is not, however, political, but rather of a natural kind: the Tumen's waters are known today for their shallowness, thereby making navigation difficult ${ }^{16}$.

21 A final issue is that of maritime boundaries. In July 1977, North Korea unilaterally introduced an economic and fishing exclusion zone of 200 miles off the coast of the Yellow Sea and, since that time the two countries have not yet settled the question of this maritime boundary ${ }^{17}$. For Peking, the North Korean position is stalling the economic development of the mouth of the Yalu and, in particular, of the Gulf of Beihai.

The territorial issue is without doubt an element of tension between China and North Korea. However, neither Pyongyang nor Peking has ever had their relations depend on resolution of the border disputes, in spite of a few violent incidents in the late 1960s. The issue is annoying for the North Korean regime, but not to the extent of risking a breakdown in relations. Since the 1980s, Pyongyang has not sought to bring the territorial issue to the fore. Accused of developing a nuclear arsenal, seriously affected by a famine since 1995-96 and with increasing economic difficulties, the DPRK can hardly dictate conditions to China. Its dependence on Peking has increased since the 1980 s, to the point where, in 1997 , North Korea's debt to the PRC exceeded US $\$ 500$ million $^{18}$.

Resolution of the territorial disputes appears to be no easy matter. China is unwilling to negotiate, given its position of force. North Korea, on the other hand, could play the card of the 1985-86 agreements reached with Russia, both with regard to case of the Tumen and Yalu rivers and to the delimitation of the maritime territory. Those accords laid out the boundary between the two countries as being in the middle of the Tumen. The few islands there are there have been placed under Korean control. Peking has studied the Russo-North Korean accords as a starting point for any future negotiations with Pyongyang. In the case of maritime boundaries, the Russo-North Korean agreement stipulates a belt of 300 nautical miles starting from the Tumen River that separates Moscow's geopolitically and economically interesting zones from those of Pyongyang.

The Russian example is important, but there are differences with respect to the Chinese case. In 1986-87, the Soviet authorities had accepted most of North Korea's claims in exchange for an improvement in relations between the two countries. The political changes at the top of the USSR (Mikhail Gorbatchev as supreme leader and Edouard Chevarnadze as Minister of Foreign Affairs) no doubt facilitated these accords. In addition, the dispute between the Russians and the North Koreans was limited to a small part of the Tumen River and the maritime zone, whereas, in the Chinese case, the disagreement is over geographical realities (the Yalu and Tumen rivers, and their islands) as well as economic ones, and also brings Korean nationalism into play (Paektusan).

Nonetheless, a rapprochement between the two countries is possible, as shown by the example of the Supung Dam, 90 kilometres upstream from the mouth of the Yalu. Built during the Japanese occupation of Manchuria in the 1930s, this one hundred-metre high dam belonged to China, being physically located in Liaoning Province. It was to enable control of the waterway as far as the river mouth. Its power station, constructed on the Korean side of the Yalu, had the capacity to provide electricity for the whole of 
Korea and Manchuria ${ }^{19}$. This station, which was damaged in the early 1940 s by floods, remained for a long time inoperative, in spite of China's regular proposal of a financial collaboration that was always rejected by North Korea. Today, it has been rebuilt and Supung Dam is one of Asia's largest, being 160 metres high and 853 metres long. It now provides electricity to the neighbouring industrial zones of China and North Korea.

Economic development can also work in favour of dispute resolution. The North Korean border zone with China and Russia now houses the project of economic development of Ranjing-Sonbong, and other border areas (like Sinuiji) have also become development zones over the past few years.

The border disputes between China and North Korea are bringing about a joining of forces between the authorities and citizens, especially in the case of Korea. Pyongyang has always tried to avoid tensions with its neighbour over Paektusan. Nonetheless, ever since 1948, the year in which the DPRK was founded, it has been fostering a nationalism aimed at China among others, denouncing the latter's imperialist past that had turned Korea into a vassal state of the Manchu emperors. By using the polemic on the nondetermination of borders, Pyongyang is bolstering this xenophobic nationalism that serves it both to display its independence from Peking, which it has in fact often called upon in the course of the past half-century, and to cover up the serious internal problems.

Pyongyang has the support of South Korea in this conflict. The authorities in Seoul are willingly lending their weight to the North Koreans in their territorial claims. This is one of the few points of agreement quickly reached by both Korean governments. In fact, Paektusan may be regarded as a symbol of national unity. Its name is even mentioned in the first verse of the Republic of Korea's national anthem. Today, however, South Koreans can only gain access to the Paektusan area from the Chinese side. Seoul's attitude can also be explained by a strategic factor: a possible future reunification of the peninsula would have to deal with these problems. For its part, Pyongyang is backing South Korea in its claim to regain Tok Island in the Sea of Japan, called Takeshima by the Japanese, who are also claiming ownership of it.

China, for its part, periodically publishes books and maps affirming the appropriation of territories even though they may still be being disputed by other countries, particularly North Korea ${ }^{20}$. The authorities in Pyongyang have identical propaganda tactics and widely display images of Kim Jong-Il and his father on top of Mount Paektusan. In spite of the pressures, Peking's leaders have been able to take the heat out of the territorial demands of the North Koreans by playing the card of Chinese aid to the Pyongyang regime. Chinese military aid was fundamental in the early 1950 s for the survival of Kim Il-Sung and his comrades from the Korean Workers' Party. Although Pyongyang attempted to play two hands at once in dealing with Moscow and Peking from the 1960s to the 1980s, since the fall of the USSR China has become North Korea's only ally internationally. In this context, Pyongyang can scarcely adopt a hard-line position over possible negotiations with Peking, and for more than a decade now has had a flexible attitude. For their part, the Chinese refuse to talk about Paektusan, and the national press very rarely gives any coverage of the territorial problems between the two countries. Peking is thus avoiding increasing tensions with Pyongyang and inflaming nationalistic passions in South Korea. 


\section{NOTES}

1. In 1963, relations between Peking and Pyongyang were at their height. Kim Il-Sung and Mao Zedong opposed Nikita Khrushchev whom they accused of revisionism. This rapprochement between the Chinese and the North Koreans resulted, in November 1963, in an agreement of co-operation and exploitation of the Yalu and Tumen rivers. This agreement also dealt with border disputes between the two countries and recognised, among other things, North Korean control over most of the islands in the two rivers. The agreement, which was very favourable to North Korea, was preceded by a visit by the Chinese President Liu Shaoqi in September.

2. Chae-Jin Lee, China and Korea: Dynamic Relations, Stanford, The Hoover Institution for War, Revolution and Peace, Stanford University, 1996, pp. 99-100.

3. Called "Paektusan" in Korean and "Baitoushan" in Chinese, in both cases this name means "white-headed mountain".

4. Or "Tianchi", the "Heavenly Lake" in Chinese.

5. Changbaishan is the largest natural reserve in China. Classified by UNESCO as a biosphere protection area, the region contains snow leopards, Siberian tigers and black bears, among other endangered species, and is the subject of studies by botanists, geologists, etc.

6. Chin O. Chung, Pyongyang Between Peking and Moscow: North Korea's Involvement in the Sino-Soviet Dispute, 1958-1975, The University of Alabama Press, 1978, p. 120. This information, which was never confirmed by either the Chinese or the North Koreans, appeared in The Indian Times of July 20th 1965, its source being a North Korean diplomat stationed in New Delhi.

7. The abandonment of the Chinese claim was preceded by a rapprochement between Peking and Pyongyang from the start of the 1970s. In January, both governments signed a navigation agreement on the Yalu and Tumen rivers; in February, a new North Korean ambassador was appointed to Peking and, a month later, a Chinese ambassador was appointed to Pyongyang. More important still was the visit to Pyongyang in April by Premier Zhou Enlai, the first by a top Chinese leader for seven years.

8. A dozen camps and museums have been set up in the Paektusan region to commemorate the Korean revolution. The Korean part of the volcano, on the site of Samjiyon, has sculptures depicting battles against the Japanese, the heroes of the revolution, generals and representatives of the people.

9. One could also mention that, since the early 1980s the Pyongyang government has been manufacturing a computer called Paektusan and that sporting competitions called the Paektusan Cup are organised every year in February, in celebration of Kim Jong-Il's birthday.

10. The Sino-North Korean dispute occasionally borders on the absurd. In the 1970s, the Chinese news agency Xinhua announced the sighting of a monster in the region. North Korea responded by saying that the "monster" was a black bear.

11. The Manchus are the second most populous minority in China after the Zhuang people in the south of the country. In the 2000 census, the latest one carried out in the country, it had 10,682 million people (Zhongguo tongji nianjian [China Statistical Yearbook], Peking, Zhongguo tongji chubanshe, 2003, p. 48).

12. Chae-Jin Lee, op. cit., p. 100. 
13. Ministry of Foreign Affairs of the People's Republic of China, Peking, November 18 th 2000.

14. Yang Tae-jin, “Territorial Dispute between North Korea and Communist China”, Vantage Point, vol. VI, nº 6, 1983, pp. 1-11.

15. Ministry of Foreign Affairs of the People's Republic of China, Peking, June 30th 2003.

16. Choon-ho Park, "River and Maritime Boundary Problems between North Korea and Russia in the Tumen River and the Sea of Japan", Korean Journal of Defense Analysis, vol. $\mathrm{V}, \mathrm{n}$ ㅇ 2, 1993, pp. 65-98.

17. Lee Yong-jin, “The Maritime Policy and Sea Law of North Korea”, Vantage Point, vol. IX, no 7, 1986, pp. 1-10.

18. David Reese, The Prospects for North Korea's Survival, London, International Institute for Strategic Studies, 1998, p. 76.

19. Yang Tae-jin, op. cit., page 6 .

20. The Chinese authorities have the support of Taipei. China has a Korean minority of about two million who live in the border provinces of Jilin (including the autonomous prefecture of Yanbian), Heilongjiang and Liaoning. The Chinese Koreans have always avoided any discord with Peking over the territorial issue with Pyongyang. See Sébastien Colin, "A Border Opening onto Numerous Geopolitical Issues. The Yanbian Korean Autonomous Prefecture”, China Perspectives, No. 48, July-August 2003, pp. 4-20.

INDEX

Subjects: relations internationales 